\title{
The effect of relationship marketing, emotional marketing and supportive marketing on customers loyalty with the mediating role of customers satisfaction: a case study (pars Abad banks)
}

\author{
Elhameh Talaneh $^{1 *}$, Kheirollah Sarboland ${ }^{2}$ \\ ${ }^{1}$ Department of Management, Germi Branch, Islamic Azad University, Germi, \\ ${ }^{2}$ Department of Management, Parsabad Moghan Branch, Islamic Azad University, Parsabad Moghan, Iran \\ *Corresponding author E-mail: elhame.talane@gmail.com
}

\begin{abstract}
In today's competitive world, the attraction and retention of customers in banking industry has become much more difficult and only those banks are successful in this competition that focuses their activities on attraction and retention of their customers. In other words, customers' satisfaction and loyalty are considered as one of the most significant objectives of banking system. Consequently, the purpose of present research is to investigate the impact of relationship marketing, emotional marketing and supportive marketing on the customers' loyalty in Pars Abad banks with the mediating role of customers' satisfaction. The statistical population of research comprises all the customers of private banks, public banks and credit and finance institutions of Pars Abad. From this population, 377 customers were selected as the research sample using random sampling method in terms of Morgan table. The questionnaires were used as the statistical instrument for data collection. The reliability of these questionnaires was confirmed using Cranach's Coefficient Alpha. The collected data were analyzed using Structural Equation Modeling (SEM) and Boot Strap. The SPSS, Lisrel and Stata software were also used in various stages of estimation. The results revealed that the customers' satisfaction plays a mediating function in the relationship between the effect of relationship marketing, emotional marketing and supportive marketing on customers' loyalty.
\end{abstract}

Keywords: Relationship Marketing; Satisfaction; Loyalty; Emotional Marketing and Supportive Marketing.

\section{Introduction}

Customer's satisfaction is regarded as one of the most important factors of success in various organizations. There is an extensive research on the relationship between customer's satisfaction with word of mouth communication, loyalty, repeat purchase and companies profitability increase [9]. In service industries where the provision of services requires creating relationship with the customers, the customer's general satisfaction is related to the staffs' relationship with them and their purchase experience from that organization. Therefore, it is not surprising that the firms allocate a considerable portion of their resources to measure and manage customer satisfaction. These firms need to investigate factors affecting on customer satisfaction and return to attain customer's loyalty [10]. Recognition of customer needs fully requires maintaining close relationships with the customer. The relationship marketing is a new approach to banking industry, which mainly aims at creating close and long-term relationships with the customer in order to attain a full understanding of the customer and his satisfaction [12]. The increasing competition between the banks at an international level has turned the attention to relationship marketing as an appropriate approach to create and maintain long-term relationship with the customers. Since the services provided at the commercial banks are fairly similar, it is difficult for most of the banks to distinguish their services from their competitors. Thus, a numerous number of banks worldwide have tended to use the relationship marketing and implement its foundations [19]. However, considering the intense competition between commer- cial organizations, it seems that the use of commercial marketing alone is not sufficient. The business managers and owners have realized that although the most important principle is creating relationship with customers, they do not succeed as they expected, their brand does not have longevity, and they have small royal customers. Consequently, we can infer that the relationship marketing is necessary, but it is not sufficient. Therefore, if the state and private banks intend to succeed in today's competitive world and achieve their objectives, they need not only to use relationship marketing approach but also the emotional marketing and supportive marketing. To achieve this goal, the Iranian banks have always tried to introduce approaches and programs for creating and maintaining long-term relationships with their customers and have their loyalty. However, planning for this issue requires banks recognition of their strength and weakness in creating relationship with customers and attaining their loyalty.

The research indicates that customers' loyalty has a significant role in success of companies business. It is to note that the loyal customers cause numerous benefits for the companies including improving organization profitability, reducing marketing costs, increasing company's sales, having customers with low price sensitivity, etc. [20]. Today, with the emergence of private banks along with state banks and an intensive competition in the Iran banking industry, it is necessary to create and maintain long-term relationships with customers to have their loyalty since the unfriendly relationships with the customers causes that a business company loses the available opportunity and be eliminated from this competition. In Pars Abad, an increase in private, banks and a 
competitive environment between banks have made the banks to attract deposits (customers), their satisfaction and loyalty in the light of relationship marketing. The present research tries to examine the effect of relationship marketing, emotional marketing and supportive marketing on the customers' loyalty with a focus on the mediating role of customers' satisfaction in Pars Abad banks. Furthermore, this study makes an attempt to investigate factors affecting customers' satisfaction and loyalty in order to introduce a model for improving their performance and to take effective steps to provide their customers with appropriate services.

\section{Review of literature and theoretical frame- work}

The intense competition and its intricacies have forced many organizations to adopt a new marketing approach, i.e. "relationship marketing" which has driven them towards defensive marketing strategies than aggressive marketing strategy. Relationship marketing involves activities, which focus on development of longterm and cost-effective relationships between an organization and customers to create a mutual profit for both parties. On the other hand, the continuous retention and enhancement of customers' relationship are the only one way road that the service organizations need to pass in order to increase their existing customers. In contrast to classic marketing theory with its emphasis on attracting new customers and performing concentrated transactions, the relationship marketing deals with creating and maintaining a longterm relationship with a customer. In this perspective, the customer retention is more important than attracting new customers. Therefore, the relationship marketing is a necessary condition but not sufficient to attain a tremendous success. To have a competitive advantage, we can use emotional marketing and supportive marketing along with relationship marketing. The emotional marketing triggers an emotional response in the customer and causes customer's emotional attachment with a brand. The cause-related marking has an influence similar to emotional marketing through allocating part of the sales revenue to public benefit and charitable purposes. Most of the researches carried out in this regard recommend that the loyal customers be preserved as a competitive asset. On the other hand, we live in a society where there is an increasing growth in business demands compared with the past. Businesses, except governmental organizations, cannot survive without having loyal customers. In addition, due to the fact that the customers' expectations are continuously increasing, the organizations are required to go further and satisfy their customers' expectations and needs and focus their attention to creating trust and loyalty through a long-term and profitable mutual relationship for both parties [8]. There are numerous researches concerning the research subject which are mentioned in the following.

Ranjbaran and Barari [1] in a research entitled as "the effect of relationship foundations on customers loyalty in Isfahan" concluded that, in state banks, the four variables commitment, trust, communication and conflict management have a significant positive impact on customers loyalty. In private banks, except the variable communications, the other variables had a significant influence on the customers' loyalty.

Ahmadi Nejad [7] in his study entitled as "examination of factors affecting the customers' behavioral and attitudinal loyalty to a brand in service sectors" investigated the effect of customer's satisfaction, customer's trust in a brand and resistance to change on customers' behavioral and attitudinal loyalty in financial service department. The statistical population of this study consisted of 162 customers of Refah bank in different regions of Shiraz. The data was collected through standardized questionnaires, and the correlation among variables was tested using Pearson Correlation Coefficient and Multiple Regression Method. The research findings indicated a positive correlation between customer's satisfaction, customer's trust in a brand and resistance to change variables and customer's behavioral and attitudinal loyalty.
Gilani Nia and Sharif [3] in a research examined the impact of relationship marketing strategy on customers' loyalty in insurance industry. The results indicated that the variables trust, commitment and communications have a positive effect on the customers' loyalty at a significant level of $0 / 05$ while the influence of conflict management on the customer's loyalty was not confirmed.

Haghighi et al. [2] investigated the effect of relationship marketing strategies on the customers' loyalty of Irancell mobile network operator. The research findings demonstrated that this company has been successful at implementing some of the relationship marketing techniques and has been able to attract the customers' satisfaction, trust and consequently, their loyalty at a significance level of $90 \%$.

Ghazi Zadeh et al. [4] in their study explored the impact of relationship marketing on customers' loyalty using ERM model in the Mellat insurance company. The results indicated that there is a significant relationship between variables investigated so that three factors of financial benefits, social factors and structural bonds affecting the quality of relationship and emotions and emotions affecting the quality of relationship can lead to customer's loyalty.

Sehat et al. [5] investigated the improvement of customers' loyalty using strategic relationship marketing approach (a case study: insurance companies affiliated with the banks. The findings of their study revealed that brand love had had the highest influence on the customers' loyalty. However, brand commitment and emotional approaches in strategic relationship marketing have had a direct or indirect influence on attracting customers' loyalty. Among the strategic relationship marketing constituents, the emotional approach has had the highest influence on the customers' loyalty.

Garshasbi and Jokar [6] studied the effect of relationship marketing on customers' loyalty of Asgariye credit and finance institution. The findings of their research showed that there is a positively significant relationship between the variables trust, commitment, communications, conflict management and competence with customers' loyalty.

Ndubisi [12] studied the dimensions of relationship marketing, i.e. trust, communications, commitment and conflict management and investigated the impact of gender as a mediating variable in the relationship between these dimensions on the customer's loyalty. The results of his research indicated that the four dimensions of relationship marketing are directly related to the customer loyalty and gender acts as a mediating variable in the relationship between customer's trust and loyalty. However, it does not play such a role in the relationship between dimensions of relationship marketing with customer's loyalty.

Terawatanavong et al. [13] examined the effect of relation marketing foundations, i.e., trust, dependency, commitment, collaborative standard variables and conflict management on the customer's satisfaction across the relationship life cycle. The results demonstrated that while the variables trust and dependency with satisfaction from the relationship during the development and maturation of relationship are closely related, the variable commitment is related to the customers' satisfaction during maturation stage.

Abdollah et al. [17] in a study examined the impact of relationship marketing techniques and relationship quality on the customers' loyalty in the Malaysian mobile telecommunication industry. The findings indicated that the relationship marketing strategies have a positive influence on the customers' loyalty.

Huang [16] investigated the effect of relationship marketing investment on the customers' gratitude and loyalty. The results demonstrated that investment in the relationship marketing through maintaining strong relationships with customers and using relationship marketing strategies can increase customers' gratitude and loyalty. 


\section{Research variables and conceptual model}

Loyalty: Oliver [21] defines loyalty as" a deeply held commitment to re-buy or re-patronize a preferred product or service consistently in the future causing repetitive same brand purchasing despite situational influences on marketing efforts." The customer's loyalty has intensity and frequency, which can be measured through the following factors: the customer is willing to enhance relationships, supports the company's products and services like a lawyer, is not volatile and susceptible to competitors offers, acts like a member of that organization, is willing to pay more price premiums, develop positive attitudes towards the new products and view himself as the company's partner.

Relationship Marketing (RM): creating relationships with customers based on collaboration, trust and commitment through real management of real transactions to deliver high-quality commodity and service, responding to customer's suggestions and views, and ignoring the short-term benefits in order to archive long-term benefits. The relationship marketing refers to creation, retention and enhancement of strong communications with the customers and other groups interested. The four dimensions of relationship marketing are trust, commitment, commutations, conflict management and competence [12]

Supportive Marketing: the process of formulating and implementing marketing activities that are characterized by an offer from the firm to contribute a specific amount to a designated cause when customers engage in revenue-producing exchanges that satisfy organizational and individual objectives [22].

Emotional Marketing: studies how to arouse emotions in people to buy that particular product/service [23]. The objective of emotional marketing is to engage customer in an active experience of brand value. When the customers have positive emotions towards a brand, the brand loyalty increases [14].

Customer Satisfaction: is defined as a customer's overall evaluation of a product or service or of a service provider after purchase [24]. The customer can be regarded as the ultimate goal in modern marketing so that a firm's success is dependent on identifying and satisfying a customer's needs and expectations. The customers' satisfaction can result in behaviors such as loyalty and word of mouth recommendation.

The variable of this research involves relationship marketing, emotional marketing and supportive marketing as independent variables, customers satisfaction as a mediating variable and customers loyalty as the dependent variable which is presented in the following conceptual; model in terms of research objectives:

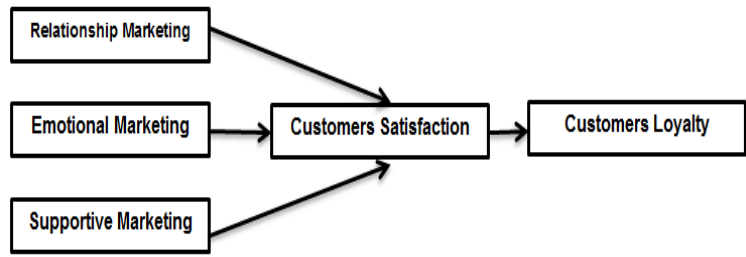

Fig. 1: Conceptual Model.

Considering the research conceptual model, the research hypotheses are as follows:

Hypothesis 1: customer's satisfaction plays a mediating role in the relationship between relationship marketing and customers' loyalty.

Hypothesis 2: customer's satisfaction plays a mediating role in the relationship between emotional marketing and customers' loyalty. Hypothesis 3: customer's satisfaction plays a mediating role in the relationship between supportive marketing and customers' loyalty.

\section{Research methodology}

From the objective view, the present research is of a practical one since the results can be used for taking effective masseurs to share organizational knowledge. From data collection perspective, the research is of a survey-descriptive type because it tries to obtain the necessary data about statistical sample using questionnaires. From chronological view, this research is cross-sectional and in terms of data, it is a qualitative research. The statistical population of research consists of all the customers of private banks, state banks and credit and finance institutions of Pars Abad. From this population, 377 customers were selected using available random sampling method in terms of Morgan Table. To collect research data, questionnaires as the statistical instrument of research were used. These questionnaires consisted of 46 questions derived from Ndubisi [12], McLuhan [14] and Oliver [21] questionnaires. Since in Likert scale, the responses are of a qualitative nature, so the alternative numbers $1,2,3,4$ and 5 were used to quantify the responses. The Cronbach's Alpha Coefficient was used to measure the reliability of questionnaires. Table 1 depicts the Cronbach's Alpha Coefficient values for questionnaires indicating that these questionnaires have an acceptable reliability.

Table 1: Reliability Coefficient of Questionnaires

\begin{tabular}{ll}
\hline Questionnaire & Cronbach Alpha \\
\hline Relationship marketing & 0.744 \\
Emotional marketing & 0.838 \\
Supportive marketing & 0.816 \\
Loyalty & 0.722 \\
Satisfaction & 0.739 \\
\hline
\end{tabular}

\section{Research findings testing and research hy- potheses}

According to Lisrel software output (Figure 2), the root square error of approximation (RMSEA) index was 0.065 which indicates the model has a highly good fit for the target population. Also, the standard Chi- square was 3.39 which is an acceptable one. Table 3 represents the model indices. The values of these indices, as we mentioned before, are satisfactory. The results of conceptual model fit indicate that all the coefficients are significant (Figure 3). To test the research hypothesis and the mediating role of indirect coefficients, the boot strap and Preacher and Hayes [18] test with STATA software were used.

Table 2: Values of Fit Indices

\begin{tabular}{lc} 
& Table 2: Values of Fit Indices \\
\hline Indices & Value \\
\hline CFI & 0.90 \\
IFI & 0.90 \\
GFI & 0.93 \\
AGFI & 0.91 \\
NFI & 0.92 \\
\hline
\end{tabular}

Hypothesis 1: customer's satisfaction plays a mediating role in the relationship between relationship marketing and customers' loyalty.

To test this hypothesis and investigating the mediating role of customer's satisfaction in the relationship between relationship marketing and customers' loyalty, the boot strap and Preacher and Hayes [18] test were used. According to Table 3, we can say that the effect of relationship marketing on customers' loyalty through customers' satisfaction is 0.5481 . Since the significant level is less than the level of error 0.05 , thus we can conclude that the customers' satisfaction has a mediating role in the relationship between relationship marketing and customers' loyalty. In other words, the hypothesis that "customer's satisfaction plays a mediating role in the relationship between relationship marketing and customers' loyalty" with $95 \%$ assurance is confirmed.

Hypothesis 2: customer's satisfaction plays a mediating role in the relationship between emotional marketing and customers' loyalty. According to the findings depicted in Table 3 , it can be said that the impact of emotional marketing on customers' loyalty through customers' satisfaction is 0.4293 . Considering that the significant level is less than the level of error 0.05 , thus it is concluded that the customers' satisfaction has a mediating role in the relationship 
between emotional marketing and customers' loyalty. In other words, the hypothesis that "customer's satisfaction plays a mediating role in the relationship between emotional marketing and customers' loyalty" is affirmed with a $95 \%$ assurance.

Hypothesis 3: customer's satisfaction plays a mediating role in the relationship between supportive marketing and customers' loyalty. As the findings of table 3 indicate, the impact of supportive marketing on customers' loyalty through customers' satisfaction is 0.3612 . Given that the significant level is less than the level of error 0.05 , thus we can conclude that the customers' satisfaction has a mediating role in the relationship between supportive marketing and customers' loyalty. In other words, the hypothesis that "customer's satisfaction plays a mediating role in the relationship between supportive marketing, and customers' loyalty" is accepted with a $95 \%$ assurance.

Table3: Boot Strap Test

\begin{tabular}{llll}
\multicolumn{4}{c}{ Table3: Boot Strap Test } \\
\hline Indices & Coefficient & Z Statistic & Sig. \\
\hline $\begin{array}{l}\text { Relationship marketing } \rightarrow \text { Satis- } \\
\text { faction } \rightarrow \text { Loyalty } \\
\text { marketing marketing } \rightarrow \text { Satisfac- } \\
\text { tion } \rightarrow \text { Loyalty }\end{array}$ & 0.5481 & 7.35 & 0.000 \\
$\begin{array}{l}\text { Supportive marketing } \rightarrow \text { Satis- } \\
\text { faction } \rightarrow \text { Loyalty }\end{array}$ & 0.4293 & 10.12 & 0.000 \\
\hline
\end{tabular}

\section{Conclusion and suggestions}

This research investigated the effect of relationship marketing, emotional marketing and supportive marketing on the customers' loyalty with the mediating role of customers' satisfaction in all the banks of Pars Abad. The research results indicate that customers' satisfaction has a mediating role in the effect of relationship marketing, emotional marketing and supportive marketing on the customers' loyalty. Generally speaking, the findings of this study are compatible with the results of various researchers, including Ndubisi [12], Ndubisi and Wah [11], Abdollah et al. [17], Terawatanavong et al. [13], Sehat et al. [5], Ranjbaran and Barari [1] and Garshasbi and Jokar [6]. In terms of research results, a set of suggestions are presented:

1) According to hypothesis (1) in which the effect of relationship marketing on customer's loyalty with mediating role of customer's satisfaction was confirmed. It is recommended that banks train their staffs to perform their tasks with high precision and accuracy. Also, it is necessary that the banks use the new technology so that they can fulfill their commitments to the customers in the shortest time possible. Besides, to increase their customers' loyalty, the banks should adapt their services to the customers' specific needs through longterm communications with their customers. Doing so, it is advised that the bank management and staffs identify each of the customer's needs and move toward providing customers with specialized services. To increase their customers' loyalty in order to create effective commutations with their customers, the banks can also inform their new service and necessary information using various public media. They can produce and distribute customers manuals related to banking rules and regulations to provide their customers with on-time and reliable information. It is also recommended that the banks hold specialized training courses in customer relationship management for their staffs, and give incentive payments to their staffs.

2) According to hypothesis (2), the impact of customer's satisfaction as a mediating role in the relationship between emotional marketing and customers' loyalty was confirmed. Thus, it is suggested that the banks managers and staffs pay attention to emotional product properties. Additionally, it is advised that the managers hold training courses for their staffs on how to deal with customers. This can have a positive effect on the customers' satisfaction and consequently, their loyalty. Moreover, the banking administrators should give much attention to the decoration and arrangement of workplace and provide their customers with a comfortable and suitable environment. This feeling of calmness can encourage the customers to return to the bank or recommend it to others.

3) According to hypothesis (3), the positive effect of supportive marketing on the customers' loyalty with the mediating role of customers' satisfaction was affirmed. Consequently, it is recommended that the bans managers and administrators to allocate part of their revenue to a public befit and charitable action because when their customers understand that bank supports a good cause, they are encouraged to return to that bank and have a strong emotion of satisfaction and loyalty to that bank.

Considering that there is not an extensive similar academic research due to lack of financial resources, time and researcher experience, thus, it is recommended that similar researches with similar variable be carried out at a national level.

1) Performing similar research in the banks and financial institutions of other provinces.

2) Comparing state banks with private banks.

3) Performing similar research in other organizations such as insurance industry, tourism industry, hotel industry, etc. to allow for generalizability of the research findings.

4) Using other marketing models in the afore-mentioned organizations.

There are also limitations to the research findings including:

1) Respondents' Lack of collaboration and inattentiveness when responding the questionnaires.

2) Another limitation of research is that the findings can only be applied to the present statistical population and are not generalizable to other populations.

3) This research was dependent on the respondents' cooperation to respond to the questionnaires. Sometimes, some of the respondents were unwilling to respond.

4) Since this study has been carried out in human and social science research area, it is possible that some of the uncontrollable variables affect the research findings. 


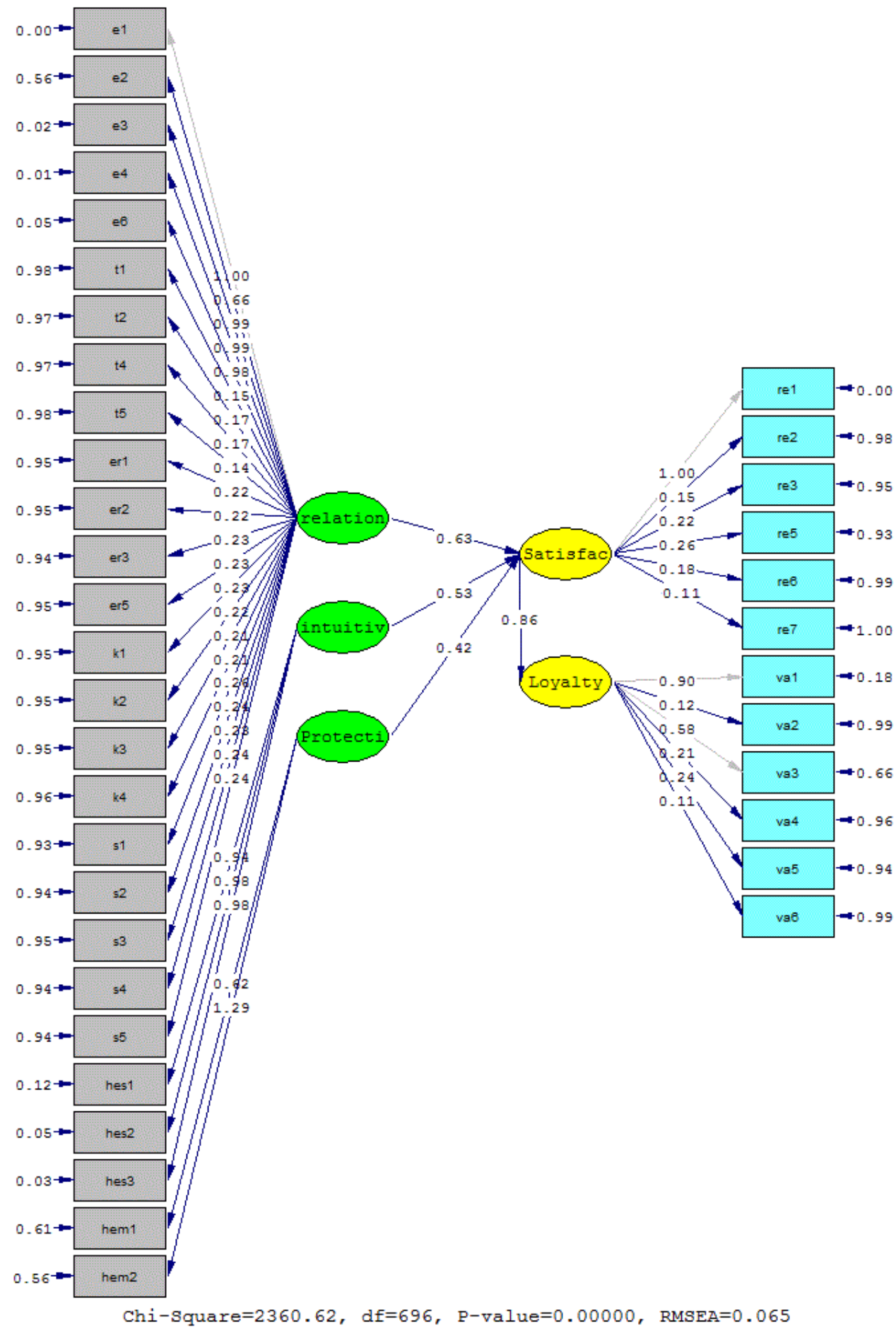

Fig. 2: Standardized Coefficients. 


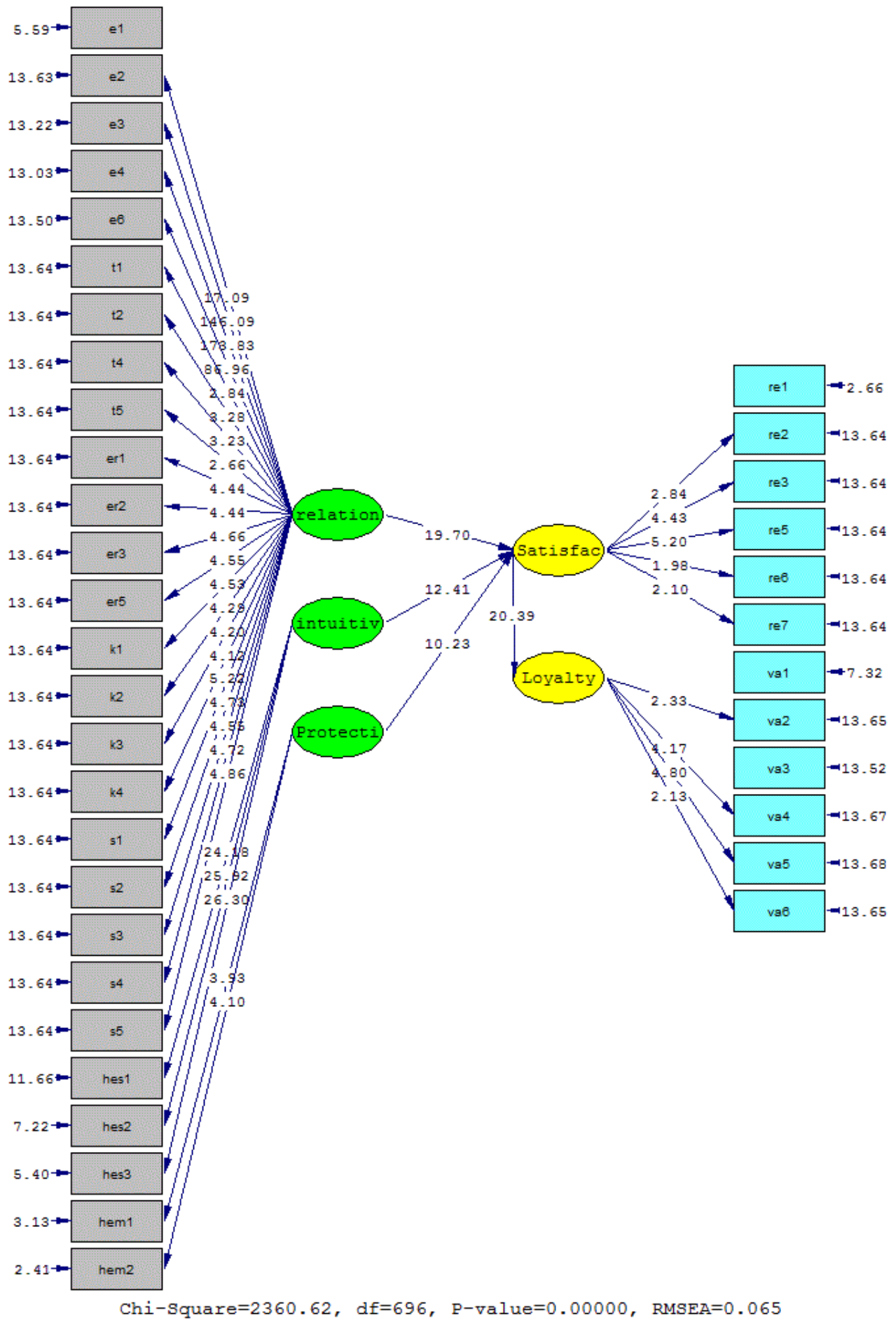

Fig. 3: Significance of Coefficients.

\section{References}

[1] Ranjbarian Mars, Barari, M, The effect of relationship marketing based on customer loyalty: comparing public and private banks". Business Management: Spring and summer 2009, Volume 1, Issue 2, [In Persian].

[2] Haghighi M, Hosseini SH, Asgharieh Ahari H, Arian A, Darikande A, A study on the effect of relationship marketing tactics on customer loyalty, Academic and research journal of modern marketing research, 2012, [In Persian].

[3] Gilani Nia and Sharif, The impact of relationship marketing strategy on customers' loyalty in insurance industry". Customer relationship management, 2012, [In Persian].

[4] Ghazi Zadeh et al., The influence of relationship marketing on customers' loyalty using ERM model in Mellat insurance company". Bimonthly Journal of Behavior, 2012, Number 47, [In Persian]
[5] Sehat et al., Improvement of customers' loyalty using strategic relationship marketing approach (a case study: insurance companies affiliated with the banks, 2015, Volume 115, pages 153-176, [In Persian].

[6] Garshasbi, M. and Jokar, J.,The effect of relationship marketing on customers' loyalty of Asgariye credit and finance institution, The Third Conference on Modern Management Sciences, 2015, [In Persian].

[7] Ahmadi Nejad, M., Examination of factors affecting the customers' behavioral and attitudinal loyalty to a brand in service sectors". International Brand Conference, 2015, [In Persian]

[8] Elahi, Shaban and Heidari, B., Customer Relationship Management", Financial Publications affiliated with commercial research and studies institution, 2009, [In Persian].

[9] Fernandez-Gonzalez, A. J and Prado, J. C. P.,Measurement and analysis of customer satisfaction: company practices in Spain and Portugal, International Journal of Productivity and Performance 
Management, 2007, Vol. 56, No. 5/6, pp. 500-517. https://doi.org/10.1108/17410400710757169.

[10] Law, A. K. Y and Hui, Y. V and Zhao, X, Modeling repurchase frequency and customer satisfaction for fast food outlets, International Journal of Quality \& ReliabilityManagement, 2004, Vol. 21, No. 5, pp. 545-563. https://doi.org/10.1108/02656710410536563.

[11] Ndubisi, N. O and Wah, C. K, Factorial and discriminant analyses of the underpinning of relationship marketing and customer satisfaction, International Journal of bank marketing, 2005, Vol. 23, No. 7, pp. 542. https://doi.org/10.1108/02652320510629908.

[12] Ndubisi, N.O, Effect of gender on and customer loyalty: a relationship marketing approach, Marketing intelligence \& planning, 2005, vol.24No.1 p48-61.

[13] Terawatanavong, C. and Whitwell, G. J. and, Widing, R. E., Buyer satisfaction with relational exchange across the relationship lifecycle, European Journal of Marketing, 2007, Vol. 41 No. 7/8, pp. 915 938. https://doi.org/10.1108/03090560710752456.

[14] McLuhan, R, Plan now, enjoy later (experiential marketing), Marketing, 2008, February 20, pp. 33-4.

[15] Abdul-Mauhmin, A. G, Effects of suppliers marketing program variables on industrial buyer relationship satisfaction and commitment, Journal of Business \& Industrial Marketing, 2002, Vol. 17, No. pp. 637-651.

[16] Huang, M.H, The influence of relationship marketing investments on customer gratitude in retailing, Journal of Business Research, 2015, Volume 68, Issue 6, 5, Pages 1318-1323.

[17] Abdullah, M. F, Lennora Putit, Carol Boon Chui Teo, Impact of Relationship Marketing Tactics (RMT's) \&amp; Relationship Quality on Customer Loyalty: A Study within the Malaysian Mobile Telecommunication Industry, Procedia - Social and Behavioral Sciences,2014, Volume 130, 15, Pages 371-378. https://doi.org/10.1016/j.sbspro.2014.04.044.

[18] Preacher, K. J., \& Hayes, A. F., Asymptotic and resampling strategies for assessing and comparing indirect effects in multiple mediator models. Behavior Research Methods, 2008, 40, 879-891. https://doi.org/10.3758/BRM.40.3.879.

[19] So, S. L. M. and Speece, M. W., Perceptions of relationship marketing among account managers of commercial banks in a Chinese environment, International Journal of Bank Marketing, 2000, Vol. 18, No. $7, \quad$ pp. 315-327. https://doi.org/10.1108/02652320010359534.

[20] Kandampully, J and suhartanto, D., Customer loyalty in the hotel industry: The role of customer satisfsction and Image, international Journal of contemporary Hospitslity management, 2000, Vol, 12No, 9, pp .346-351.

[21] Oliver, R.L., Whence consumer loyalty? Journal of marketing, 1999, Vol.63, pp.33-44. https://doi.org/10.2307/1252099.

[22] Varadarajan, R.P. and Menon, A., Cause-related marketing: a coalignment of marketing strategy and corporate philanthropy, Journal of Marketing, 1988, Vol. 52 No. 3, pp. 58-74. https://doi.org/10.2307/1251450.

[23] Domenico, C., A, new concept of marketing: The emotional marketing, Broad Research in Accounting, Negotiation, and Distribution, 2010, 1 (1), pp. 52-59.

[24] Sharma, N and Patterson, P. G, Switching costs, alternative attractiveness and experience as moderators of relationship commitment in professional, consumer services , International Journal of Service Industry Management,2010, Vol. 11, No. 5, pp. 470-490. https://doi.org/10.1108/09564230010360182. 